\title{
Work zones of Novi Sad (Vojvodina, Serbia) with examples of industrial transformation
}

\author{
Dragan D. Milošević ${ }^{*}$, Jasmina Đorđević ${ }^{B}$ \\ Received: October 20, 2014 | Revised: January 22, 2015 | Accepted: February 25, 2015
}

\begin{abstract}
In this paper are presented historical industrial development and present industrial distribution in Novi Sad, the second largest city in the Republic of Serbia and the largest city of the Autonomous Province of Vojvodina.

At present, industrial facilities in the city are located in work zones, at the entrance traffic routes to the city and the surrounding settlements, on individual sites within other city function areas or within the lots of family housing. Nevertheless, established work zones are main areas for industrial development of the city.

Novi Sad has seven work zones: "Sever I", "Sever II", "Sever III", "Sever IV", "Rimski Šančevi", "Zapad" and "Istok" that occupy 1761.9 ha. There are significant opportunities for economical development in these work zones, both on unconstructed surfaces and in the present complexes.

Unfortunately, due to the crisis of industry in Serbia, numerous industrial facilities in the work zones of Novi Sad are neglected. In this paper are given examples of transformation of neglected industrial facilities and use of unconstructed area in work zone in Novi Sad. Transformation of industrial facilities within work zones is present in many cities (Budapest, Bucharest, Zagreb, Maribor, Milano, Krakow, New York) with positive examples.
\end{abstract}

Key words: industry, work zones, transformation, Novi Sad, Vojvodina, Serbia.

\section{Introduction}

Transition has generated a crisis of industry in all post-socialistic European countries, but nowhere else was the crisis so destructive as it was in Serbia. Due to economic, political and transitional issues, the situation in Serbia was such that in the 1980 os the number of workers employed in industry was around 1,000,000 whereas twenty years later that number was reduced by one half. This was not the result of upgraded and modernized industry, but of the tremendous changes in politics, regional development policy as well as the increase of unemployment rate and more expressive social differences (Grčić, Ratkaj, 2006).
While some towns and regions were capable of adjusting successfully to a newly created situation (e.g. Rhur area) (Ćopić, et al., 2014), the other ones are facing major issues, which have considerably weakened their position on local and regional scale (Miletić, et al., 2009).

The example of Serbia reports that large centers took most of the crisis burden, whereas the small centers appeared more flexible and adaptable to changes. The conclusion is that the most stable are middle sized centers, i.e. Ruma, Inđija and Smederevo in Serbia. In large centers changes had a bad impact on the development of industry, which caused stagnation and dis-

A Climatology and Hydrology Research Centre, Faculty of Science, University of Novi Sad; Trg Dositeja Obradovića 3, 21000 Novi Sad, Serbia

B University of Novi Sad, Faculty of Science, Department of Geography, Tourism and Hotel Management, Trg Dositeja Obradovića 3, 21000 Novi Sad, Serbia

* Corresponding author: Milošević Dragan, e-mail: dragan.milosevic@dgt.uns.ac.rs 


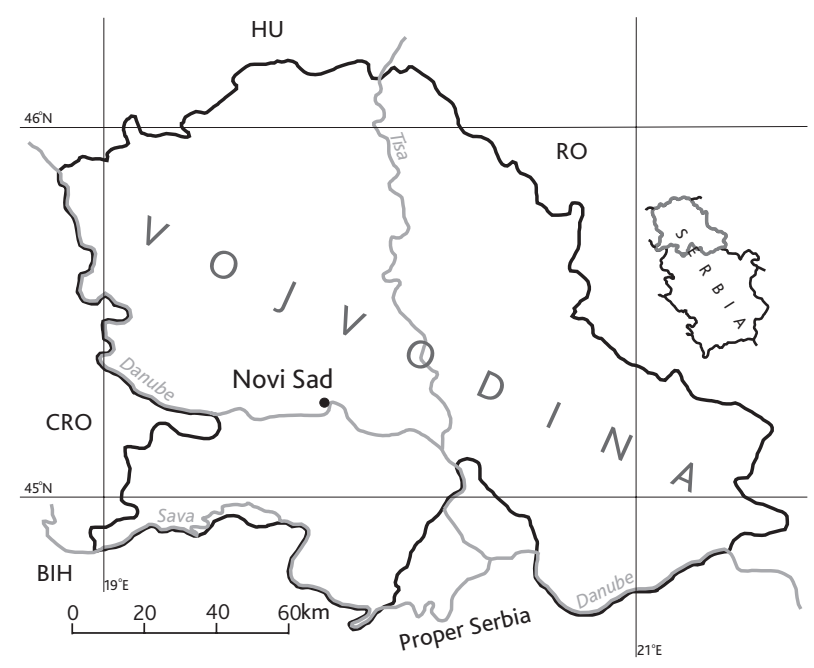

Figure 1. Geographical location of Novi Sad Source: Savić et al., 2013

couragement in industry (Grčić, Ratkaj, 2003). As the second largest city in the country, Novi Sad did not sufficiently adjust its industry to the newly created situation.

Novi Sad is located in the northern part of the Republic of Serbia (Figure 1) and in southeastern part of Pannonian Plain. It is the second largest city in the country with a population of about 320,000 in a builtup area of around $80 \mathrm{~km}^{2}$ (Savić, et al., 2013).

\section{Industrial development of Novi Sad}

The beginning of the industrial development of Novi Sad could be traced back to the first half of the 19th century when a textile factory was built (Stajić, 1941). Opening of the factories continued in the period af ter World War II. In addition to the already developed industrial sectors (e.g. textile and food), priority was given to the refining, metal processing, chemical and electro industries. About $27 \%$ of population in Novi Sad was industrial workers in the '8os. In 1994 on the territory of the city were located 56 industrial facilities (Bogdanović, et al., 1994).

At the time of the first post-war Plan of Novi Sad in 1950, the industry facilities were concentrated at following city areas:

- Near the railroad station,

- Mali Liman,

- Podbara and

- Between Kotorska and Šumadijska Street (Bogdanović, et al., 1994).

Original location of industrial facilities became unfavorable with time because of the process of urbanization. Industry occupied central parts of the city surrounded by residential buildings. It was necessary to relocate industrial facilities in order to provide the conditions for faster city development and expansion of industrial capacities. This problem was treated with the Master Plan of 1950 which recommended that industrial facilities should be located along the right bank of the Savino Selo - Novi Sad channel and on the northeastern part of Petrovaradin. Danube, channel and the direction of dominant winds, primarily Košava (SW - NE), were the dominant factors in choosing these locations for industry. In addition to that, railway relocation and constructions of roadrailway bridge over the Danube, cargo ports, mills and silos at the port were carried out (Bogdanović, et al., 1994).

However, after a decade there has been a revision of the Master Plan. It was realized that the new areas for industrial development were insufficient. After that, the spatial plan for the creation of industrial zones was proposed. For industrial development were intended new areas in the northern part of the city on the right and left bank of the channel, near the new railway station and a new industrial zone was created next to the Futoški put Street. The latter zone was intended only for the development of light industry because it was located in the residential areas of the city. Relocation of the majority of the industrial capacities from the inner city areas to the new locations in the peripheral areas happened in the period from 1961 to 1971 (Bogdanović, et al., 1994).

The Assembly of the City of Novi Sad passed the latest Spatial Plan of the City of Novi Sad in 2012. The plan covers the territory of the City of Novi Sad, which includes the areas of cadastral municipalities: Novi Sad I, II, III and IV, Futog, Veternik, Begeč, Kisač, Rumenka, Stepanovićevo, Kać, Čenej, Budisava, Kovilj, Petrovaradin, Sremska Kamenica, Bukovac and Ledinci. The plan includes surface area of 69,917.23 ha. Based on a comparison of planned and existing land use, a reduction in agricultural land by $3.06 \%$ and enlargement in building land by $1.22 \%$ was observed (Official Gazette of the City of Novi Sad, 2012).

In the City of Novi Sad there were 127,607 employed persons at the end of September 2013, which is 20,373 less than in September 2008 (14.69\% reduction) or 2,593 less ( $1.99 \%$ reduction) compared to September 2012. In manufacturing industry were employed 12,544 people that represented $9.8 \%$ of the total number of persons employed in Novi Sad in September 2013. More employees in Novi Sad had only private entrepreneurs, trade and health services (Tabe 1) (Press releases of the Statistical Office of the Republic of Serbia, January 2014, July 2013, January 2013, January 2012 and January 2009). The number of industrial workers in Novi Sad continues to decrease due to the closing of the industrial enterprises in the city. 
Table 1. Employment by sector activities in the City of Novi Sad in the September 2008 - September 2013 period

\begin{tabular}{|c|c|c|c|c|c|}
\hline Activity & SEP 2008 & SEP 2011 & SEP 2012 & MAR 2013 & SEP 2013 \\
\hline Agriculture, forestry, water management and mining & 2277 & 1452 & 1504 & 1696 & 1468 \\
\hline Extraction of ore and rock & 1011 & 644 & 1425 & 1323 & 1186 \\
\hline Manufacturing industry & 18301 & 15462 & 13983 & 13488 & 12544 \\
\hline Production of electricity, gas and water & 1881 & 1428 & 1528 & 1639 & 1799 \\
\hline Construction & 9636 & 7785 & 7130 & 7102 & 6593 \\
\hline Wholesale and retail & 17136 & 17228 & 16519 & 16575 & 16312 \\
\hline Hotels and restaurants & 1182 & 1333 & 1205 & 1184 & 1139 \\
\hline Transport, storage and communication & 6709 & 5738 & 5140 & 5156 & 6105 \\
\hline Financial intermediation & 3967 & 4243 & 4268 & 3618 & 3864 \\
\hline Real estate & 7369 & 346 & 369 & 377 & 398 \\
\hline Public administration and social security & 4131 & 14949 & 5213 & 5196 & 5288 \\
\hline $\begin{array}{l}\text { Professional, scientific, technical, inovative, } \\
\text { administrative and support service activities }\end{array}$ & - & - & 9359 & 9594 & 10176 \\
\hline Education & 9210 & 10126 & 9983 & 10209 & 10255 \\
\hline Health and social services & 11832 & 12720 & 12510 & 12567 & 12552 \\
\hline Information and communication & - & 4857 & 5697 & 5839 & 5095 \\
\hline Other community, social and personal services & 5995 & 4904 & 4935 & 4990 & 5760 \\
\hline Private entrepreneurs and their employees & 48938 & 32719 & 29432 & 28649 & 27073 \\
\hline Total & 149575 & 135934 & 130200 & 129202 & 127607 \\
\hline
\end{tabular}

Source: Press releases of the Statistical Office of the Republic of Serbia (January 2014, July 2013, January 2013, January 2012 and January 2009)

\section{Distribution of industrial activities in Novi Sad}

Areas devoted to economical activities in Novi Sad and surrounding settlements are defined with spatial and urban plans. Industrial facilities are located in work zones, at the entrance traffic routes to the city and the surrounding settlements, on individual sites within other city function areas or within the lots of family housing (Official Gazette of the City of Novi Sad, 2012).

For economical development were established work zones in Novi Sad. Spaces designed for this purpose are organized into seven work zones: Sever I, II, III and IV, "Rimski Šančevi", "Istok" and "Zapad" (Figure 2). These work zones are committed to the development of secondary and tertiary activities, except for the work zone "Sever III" that is devoted to the development of the port, transport of goods and logistics center and work zone "Zapad" oriented towards the integration of a tertiary sector activities compatible with housing function of the area.

Total surface area of the work zones is 1761.9 ha. There are significant opportunities for economical development in work zones, both on free surfaces and in the present complexes. However, significant investments are required in the infrastructure of the area for the realization of its planned purposes (Official Gazette of the City of Novi Sad, 2012).
In addition to work zones within the city and the surrounding settlements, other areas for the development of economic activities are planned. Those are primarily areas surrounding entrance routes in the city planned for the development of primarily tertiary activities and entrepreneurship. They are equipped, have access to the infrastructure and are located along the main roads that make them favorable for the economical development. Areas located near the entrance routes occupy about 577 ha. An important realization of economical development was achieved at Rumenka, Veternik and Temerin entrance route. In the area of Zrenjanin entrance route are more initiated than realized activities because of the underdeveloped infrastructure (Official Gazette of the City of Novi Sad, 2012).

Large economical complexes that do not meet the locational criteria (ea. organizational, environmental, etc.) are found in various parts of the city. Economical complexes that have to be relocated are: "Brodogradilište Novi Sad", "DES d.p. Novi Sad", "Vagar" and "Elektroporcelan" (Official Gazette of the City of Novi Sad, 2012).

\section{Work zones}

Ortophoto images with the resolution from $10 \mathrm{~cm}$ to $40 \mathrm{~cm}$ for the period 2007-2010 were used for the mapping of the work zones. These images are provided by 


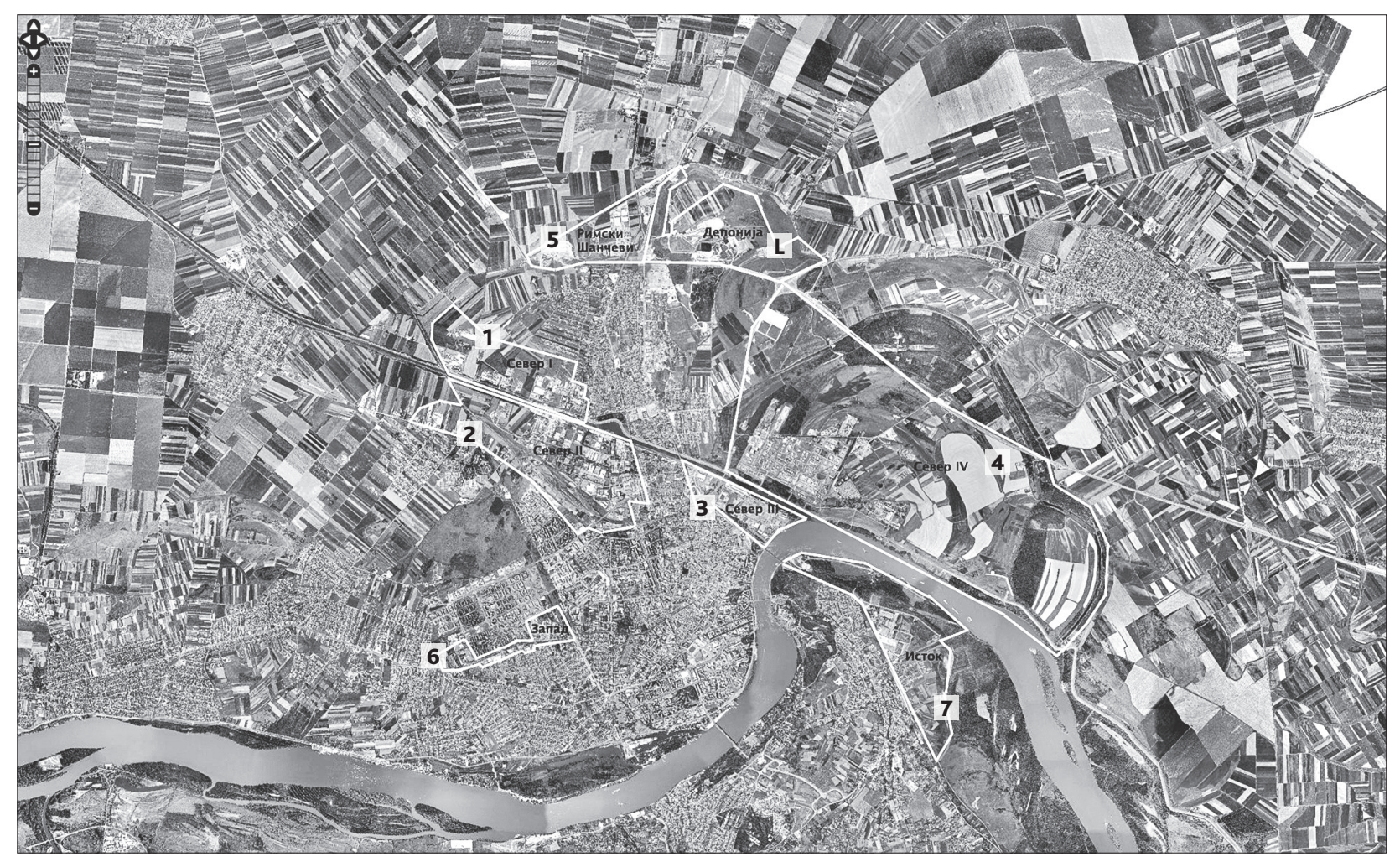

Figure 2. City of Novi Sad with marked work zones locations: 1- work zone "Sever I", 2 - work zone "Sever II", 3 - work zone "Sever III", 4 - work zone "Sever IV", 5 - work zone "Rimski Šančevi", 6 - work zone "Zapad", 7 - work zone "Istok" and L - City landfill. Scale 1:36871.

Source: author's work according to Internet 1, scale 1:37000

the Republic Geodetic Authority and are available on the national geoportal "Geosrbija" (Internet 1).

Industrial zone "Sever" is the largest among work zones. It is located on the left and right bank of Danube - Tisza - Danube (DTD) channel and on the left bank of the Danube. Due to its large area (>150o ha) it is divided into four smaller zones: "Sever I", "Sever II", "Sever III" and "Sever IV".

Work zone "Sever I", also known as the Industrial Zone Sever, is located north of the DTD channel, near the city's quarters Klisa and Gornje Livade (Figure 3). About 90 ha of the zone are free space and it is mostly state-owned. Road traffic is available and one part of the complex has a railway connection through the station "Gornje Sajlovo". Water supply does not meet current users needs and disposal of wastewater has not been resolved. Supply of electricity meets the users needs in the work zone. Industry that creates technological waste that needs to be deposited and neutralized on the spot cannot be developed in the zone (Official Gazette of the City of Novi Sad, 2006).

Companies located in this work zone are: "Yuhor" (meat products industry), "Tehnogas" (production of gas), "Novograp" (construction company), "Mikom" (steel constructions), "Koteksprodukt" (pharmaceutical and food products), JKP “Ciklonizacija”, etc.
Work zone "Sever II", also known as the Industrial Zone Jug, is located south of the DTD channel, near the city's quarters Salajka, Pervazovo naselje, Banatić, Detelinara, Avijatičarsko naselje, Jugovićevo and Sajlovo (Figure 4). About 45 ha of the zone are free space. The zone is mainly related towards road traffic, but relies on the railway junction, also. This provides an opportunity for more intensive use of these types of traffic. Disruptions in water supply occur due to the use of sanitary water for technological purposes. For high-quality electricity power supply of the zone it is necessary to

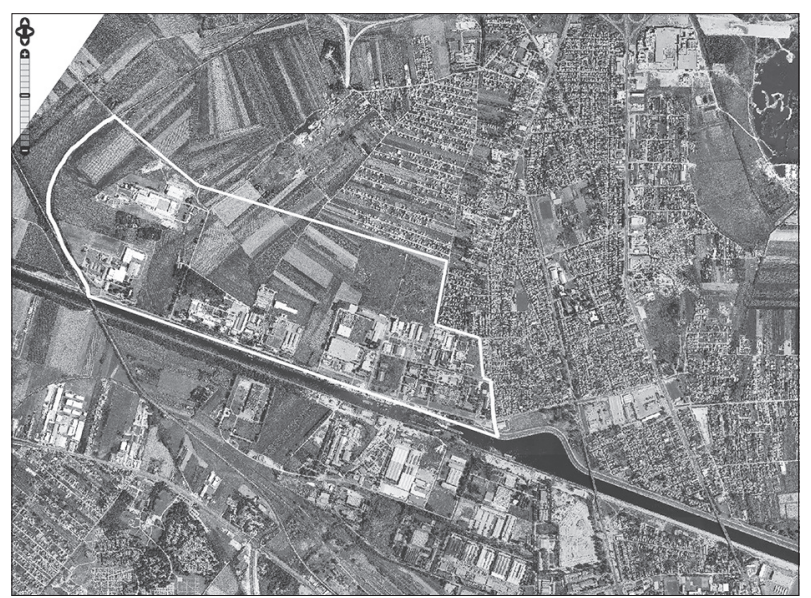

Figure 3. Work zone "Sever I" in Novi Sad Source: author's work according to Internet 1, scale: 1:10000 
build the planned thermal station TS $110 / 20 \mathrm{kV}$ "Klisa". Supply of thermal energy is not resolved. The land is mostly privately owned. Industry that requires large spaces and large amounts of water, if disorders of water supply are resolved, could be located in this work zone. Industry that creates waste that needs to be deposited and neutralized in the zone is not proper for this zone (Official Gazette of the City of Novi Sad, 2006).

In this work zone are located: "Novkabel" (cable factory), "Mašinoremont" (metal parts and accessories), "Motins" (formerly "27. Mart", parts for the automotive industry), "Limprodukt" (metal packaging), "Albus" (hygiene products and cosmetics), company "Standard", meat industry "Matijević", department store "Merkur", "Novosadska Mlekara" (dairy products), etc.

Work zone "Sever III" is located in the northern part of the city quarter Podbara and south of the DTD channel (Figure 5). About 10 ha of the zone are free space. Pier and storage areas occupy the largest part of the work zone. Zone relies on three kinds of transport. The industrial railway passes through the zone and there are satisfactory conditions for the operation of water and road transport. In this work zone cannot be located facilities that pollute the environment (Official Gazette of the City of Novi Sad, 2006).

In this work zone are located: Luka Novi Sad (port complex), large mill with silos, factory of pasta and bread "Danubius", supermarket "Tempo", factory "Agrohem" (production of fertilizers) currently in bankruptcy, etc. The work zone "Sever III" also includes a few commercial buildings at the city quarter Salajka.

Work zone "Sever IV" is the largest industrial zone in the city. It is located on the northeastern outskirts of Novi Sad, near the city districts of Šangaj, Mali Beograd, Mišin Salaš and Veliki Rit (Figure 6). In this work zone is located refinery that has been severely damaged during the 1999 NATO bombing. The Russian company Gazprom Neft and the Republic of Serbia are the owners of the refinery. Work zone has a surface area of about 700 ha with only 274.6 ha of area used. The largest part of the available free space will be used for the construction of a regional pier. Zone has a connection with national road M-7, also railroad connection through the station "Grbavica" while water transport is available through the DTD channel. Due to the proximity of water sources, special measures of protection will be applied (Official Gazette City of Novi Sad, 2006).

In this work zone is located thermal power and heating plant "Novi Sad" which is the major energy facility in the city. The reconstruction and expansion of the station and building of a new steam plant facility are planned. The main source of energy that will be used in the plant will be natural gas (Official Gazette of the City of Novi Sad, 2012).

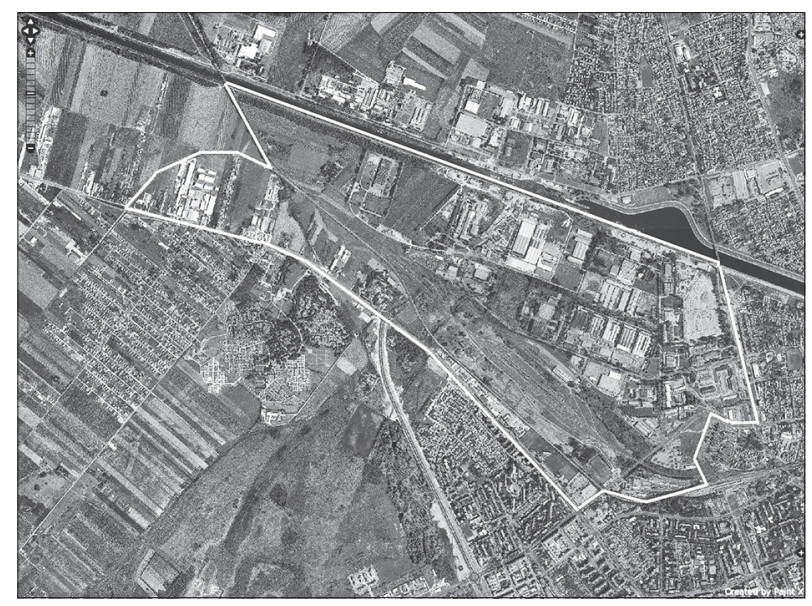

Figure 4. Work zone "Sever II" in Novi Sad Source: author's work according to Internet 1, scale: 1:10000

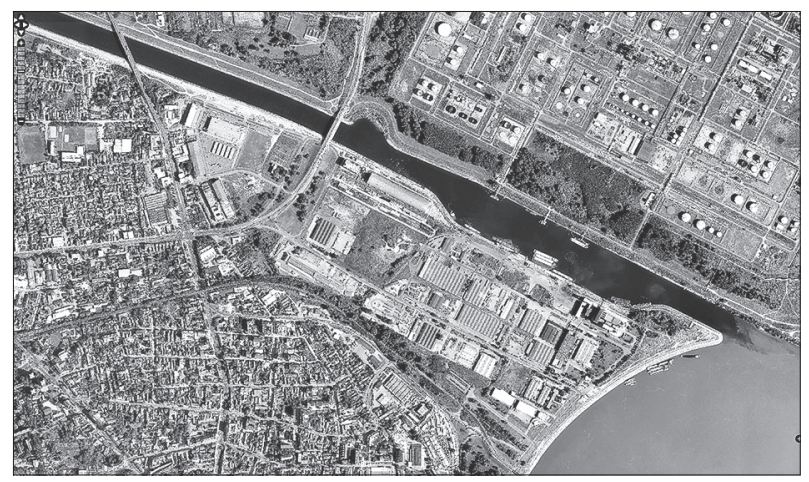

Figure 5. Work zone "Sever III" in Novi Sad Source: author's work according to Internet 1, scale: 1:5000

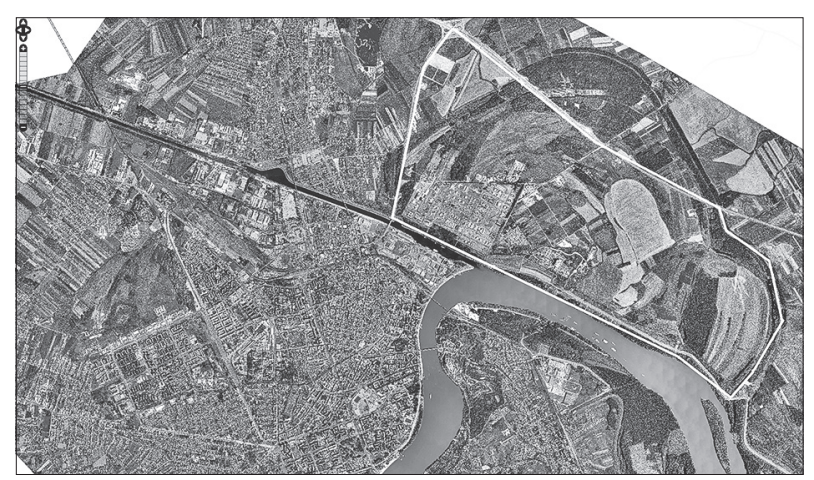

Figure 6. Work zone "Sever IV" in Novi Sad

Source: author's work according to Internet 1, scale: 1:20000 


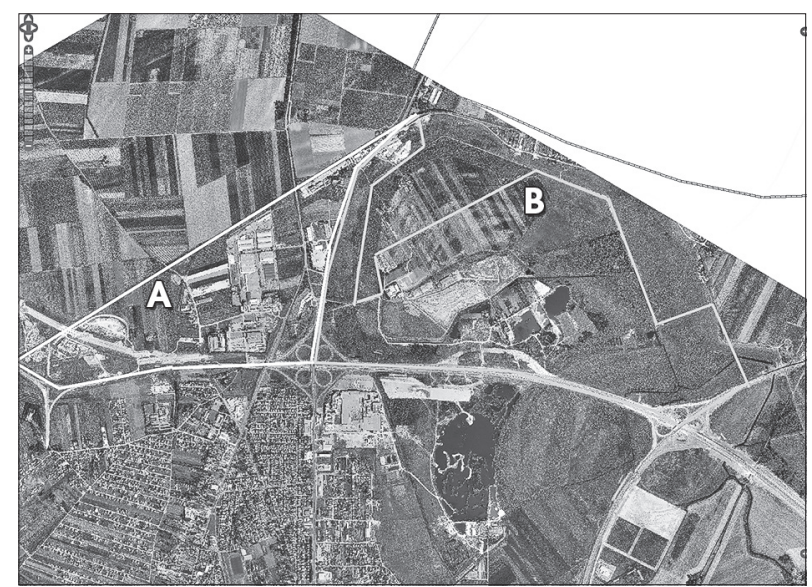

Figure 7. Work zone "Rimski Šančevi" (A) and city landfill (B) in Novi Sad

Source: author's work according to Internet 1, scale: 1:10000

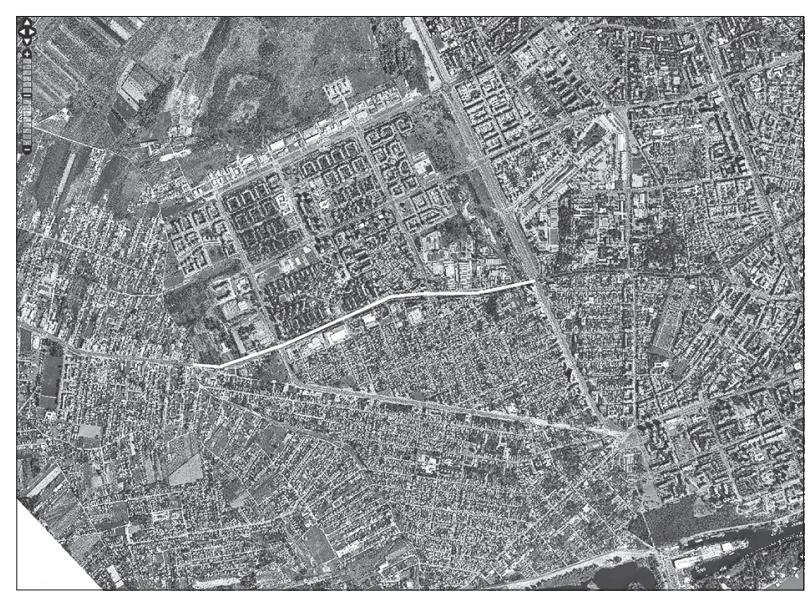

Figure 8. Work zone "Zapad" in Novi Sad

Source: author's work according to Internet 1, scale: 1:10000

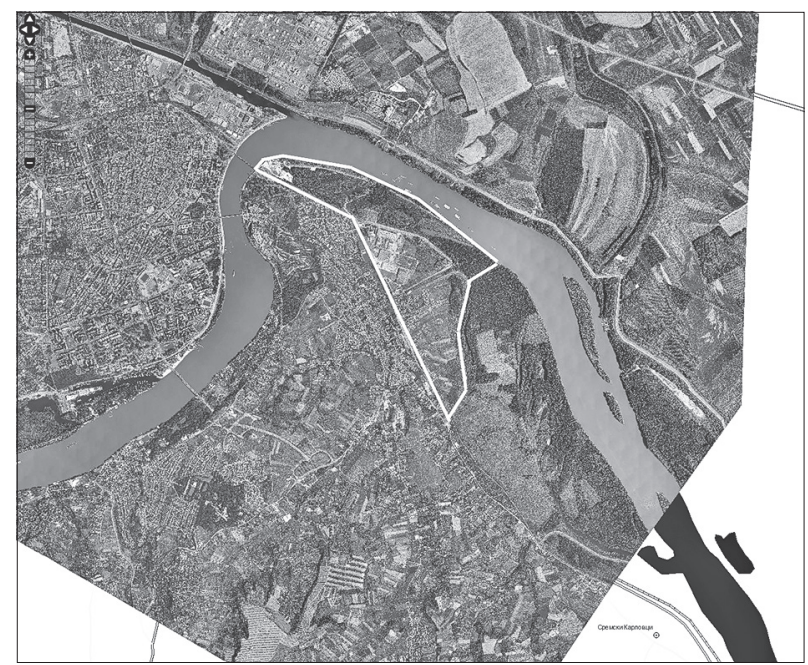

Figure 9. Work zone "Istok" in Petrovaradin

Source: author's work according to Internet 1, scale: 1:24000
Work Zone "Rimski Šančevi" is located in the northern outskirts of the city, close to the city quarters Klisa and Gonje Livade and International road and Temerin road (Figure 7). Here are located company "Mlinoservis" and warehouses. Free space occupies about 13 ha of the zone and is mostly privately owned. Work zone is oriented towards road traffic and partly to the rail traffic. In this work zone will be located activities that have approximately the same locational requirements as the current companies (Official Gazette of the City of Novi Sad, 2006).

City landfill is located in the northern outskirts of the city, east of the work zone "Rimski Šančevi" (Figure 7). It is planned that the local government will promote the existing municipal landfill into regional landfill (Official Gazette of the City of Novi Sad, 2012).

Work zone "Zapad" is located north and south of the Futoški put road (Figure 8) at city quarters Novo Naselje and Telep. In this zone are located companies "Novitet" (footwear and clothing), "AMB - Grafika" (paper, cardboard and flexible packaging), "Alba" (neon signs), "Avala Kolor" (paints and varnishes), "Jugoalat" (tools production), "Jugodent" (dental equipment), "Dunav" (production of orthopedic devices), "Javno gradsko saobraćajno preduzeće" (public transportation company), etc. Free space occupies about 34 ha of the work zone. In this zone cannot be located activities that could endanger environment, primarily residential parts of this zone (Official Gazette of the City of Novi Sad, 2006).

Work Zone "Istok" is located on Petrovaradin (Figure 9). Free space occupies about 85 ha of the zone. It is oriented towards road and rail traffic through railway station in Petrovaradin.

This work zone is planned for business, sports, entertainment, hospitality and housing, and due to the proximity of housing estate and protected nature here has to be applied strict protection measures (Official Gazette of the City of Novi Sad, 2006). The most important company in this industrial zone is "Pobeda" with a variety of metal processing program.

\section{Industrial transformation of work zone "Sever III"}

In the work zone "Sever III" are located: pier, industrial facilities, unconstructed and green areas and old buildings of former chemical industry and refrigerator company.

In this paper are given examples of transformation of old industrial objects of "Agrohem" and "Centroslavija" companies and an example for the use of unconstructed land (Figure 10). 


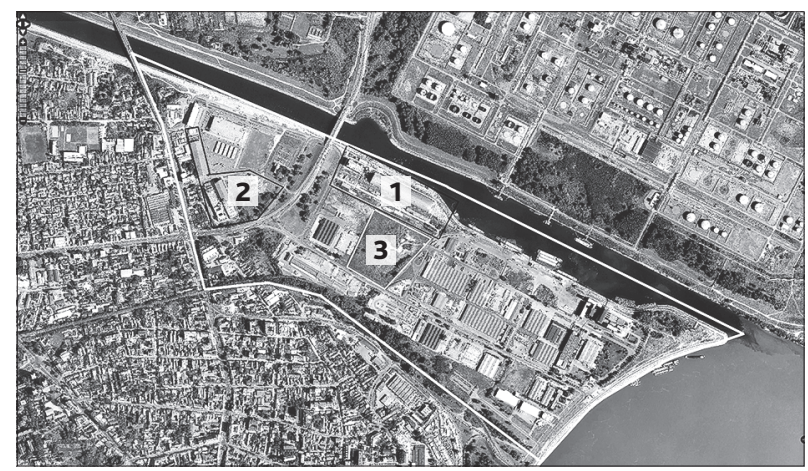

Figure 10. Boundary of the work zone "Sever III" in Novi Sad with marked areas of the zone planned for transformation: 1 - "Agrohem", 2 - "Centroslavija" and 3 Unconstructed land

Source: author's work according to Internet 1, scale: 1:5000.

\section{Transformation of "Agrohem" facilities}

Company "Agrohem" was producing fertilizers, nitrogen compounds, pesticides and soaps and detergents for cleaning and polishing. It was one of the leading producers of mineral fertilizers in Serbia. In line with global trends, "Agrohem" had applied so called blending technology that attained a considerable savings in energy and belongs to a class of technologies that do not pollute the environment. Unfortunately, the company that was a pride of the city has become its mockery. When entering to the city from the north direction, visitors can see abandoned buildings of former "Agrohem" (Figure 11).

One of the solutions for the transformation of the former "Agrohem" facilities is the construction of shopping center on its place (Figure 12). The project was made and at the former site of the company should be build a shopping center called "River Plaza" back in 2010. Before that, large mill and big tanks were removed from the area. Also, concrete foundations of reservoir were demolished and only empty buildings remained. The construction did not start as investors "East Real Holding" with headquarters in Vienna have given up on the project for now. It is likely that on making such a decision had an impact the construction of "BIG" shopping center in the near by working zone "Sever IV".

Construction of a shopping center on the site of abounded buildings would lead to the development and revival of the neighborhood, as well as the employment of people that is very important during the current economic crisis. Also, the shopping center would be built in a prime location near the DTD
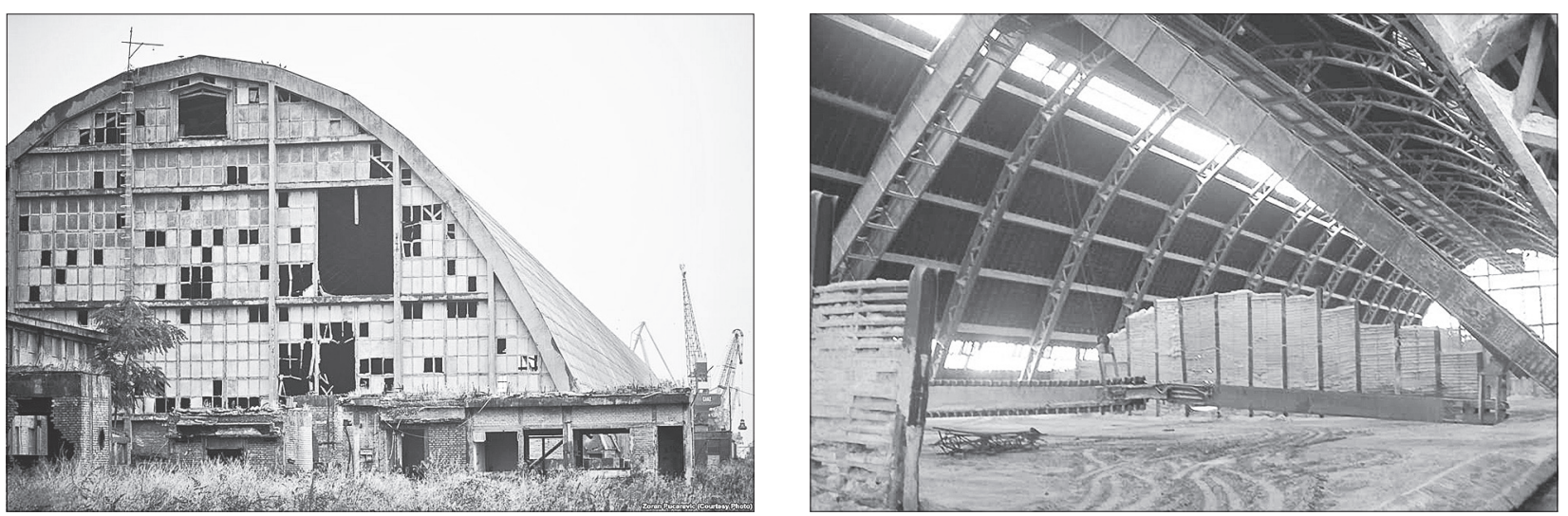

Figure 11. The abandoned buildings of the former "Agrohem" company Source of photo a: Internet 2; Source of photo b: Internet 3
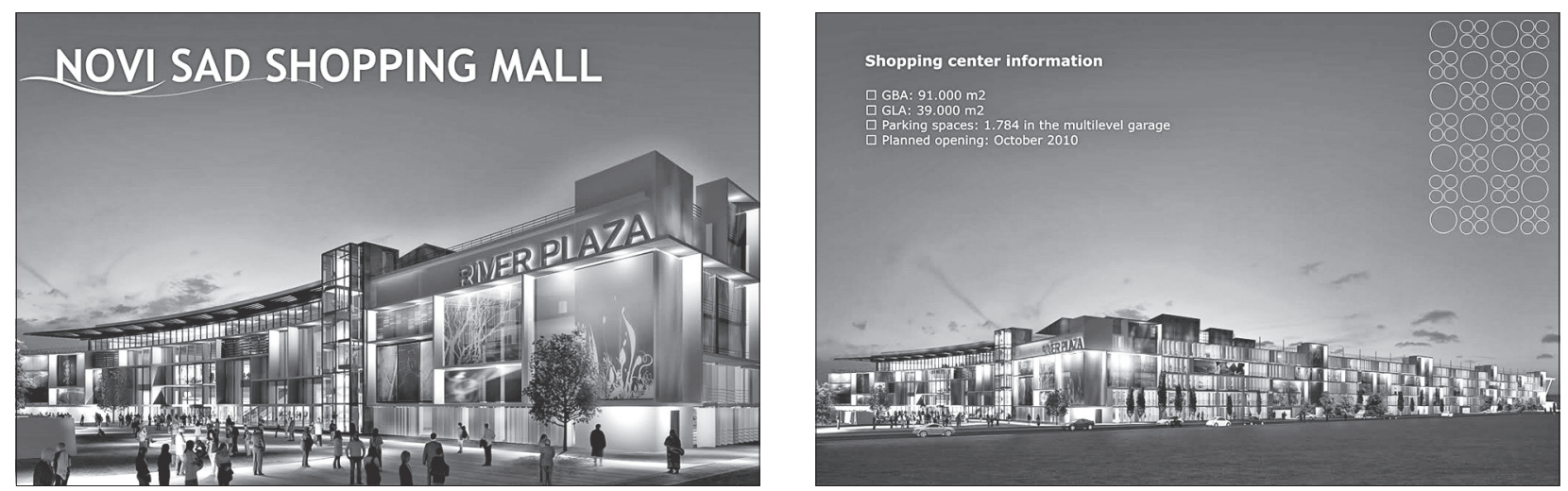

Figure 12. Vision of shopping center "River Plaza" on the site of the former "Agrohem" company. Source of $a$ and b photo: Internet 4 

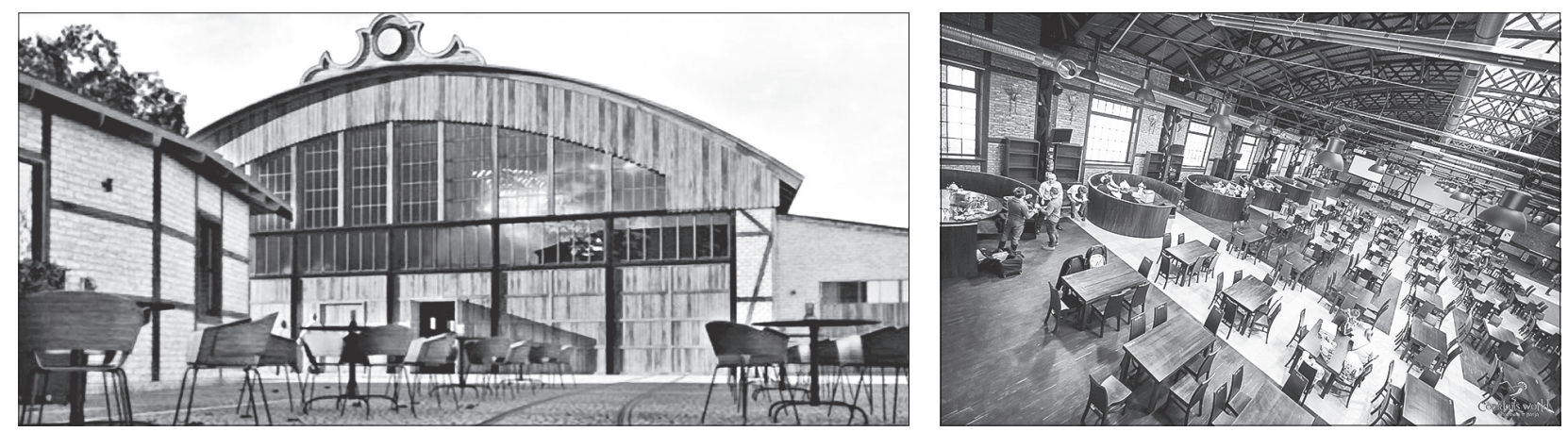

Figure 13. Vision of planned Restaurant located in the site of the former "Agrohem" company.

Source of photo a: Internet 6; Source of photo b: Internet 7

channel with excellent visual effect. Inevitably it would be important and necessary to regulate a promenade along the DTD channel. Also, pedestrian and bicycle path could be built in order to connect "BIG" and "River Plaza" shopping centers.

Another example of transformation of this area is found in Krakow, the former capital of Poland. The space used for trams station in this city has been renovated and transformed into a modern and luxurious restaurant for 700 guests (Internet 5). It is the largest number of guests that can fit in one restaurant in this city. Since the building of the former tram station in Krakow and industrial buildings of "Agrohem" in Novi Sad are similar in shape and size (Figure 13), the idea is that abandoned industrial hall would be transformed into a modern restaurant that will serve for the cultural and entertainment events.

\section{Transformation of "Centroslavija" facilities}

Former Novi Sad commercial giant Social Enterprise Holding "Centroslavija" began to collapse in the late 1980 os. Today are left only abandoned buildings, warehouses and cold storage of former "Centroslavija" (Figure 14). Examples of repurposing of abandoned warehouses can be applied for the facilities of former "Centroslavija".

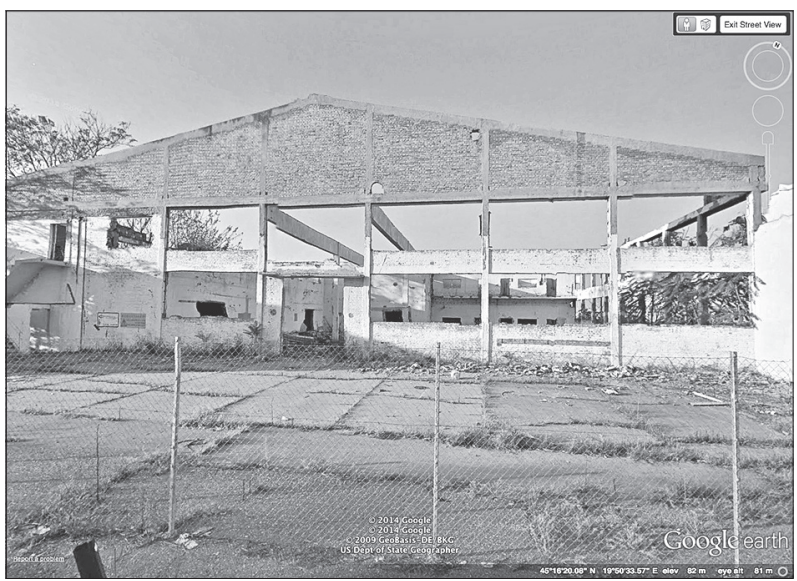

Figure 14. Abounded facilities of former "Centroslavija" Source of a and b photo: Google Earth (street view), 2014
Abandoned warehouses in many cities around the world are transformed and are given a new purpose. One example of repurposing of such objects can be found in Brooklyn, one of the five metropolitan areas of New York City (United States of America). The two former industrial warehouses have been transformed into a building with retail stores. Movable steel wall that opens and discovers the doors and windows in the building was designed and installed.

The facade has two functions: during the day it creates shade and allows passers-by to rest beneath it, while at night it protects the building from potential burglars (Figure 15). Also in the building are built in LED lights that emit glow at night through holes drilled in stainless steel facade. This material was chosen because it embodies the former industrial function, but at the same time is artistic. Inside the building are wine store, an organic market, etc. (Internet 8). Part of the free space behind the building could be used for building of a parking lot.

\section{Transformation of the unconstructed area of work zone "Sever III"}

South of the former company "Agrohem" is located vacant and unconstructed area with size of $230 \times 220$ $\mathrm{m}$ (Figure 16). This space could be used for construc-

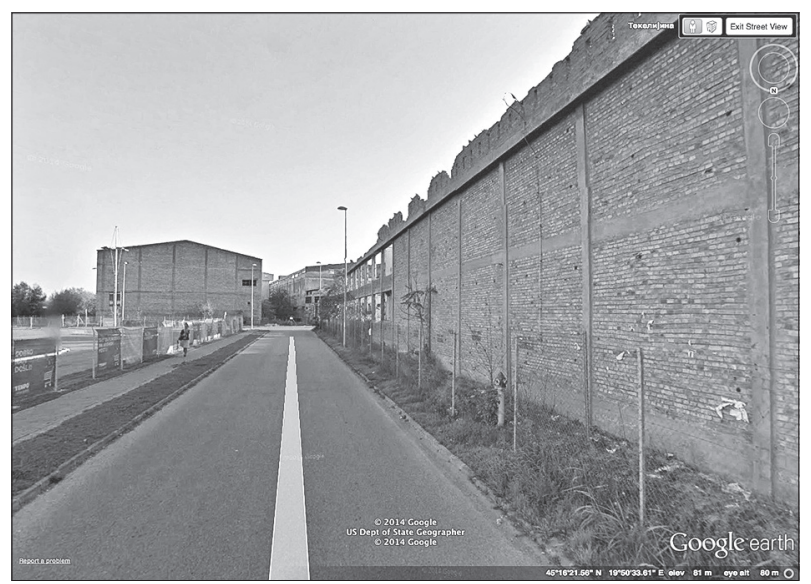



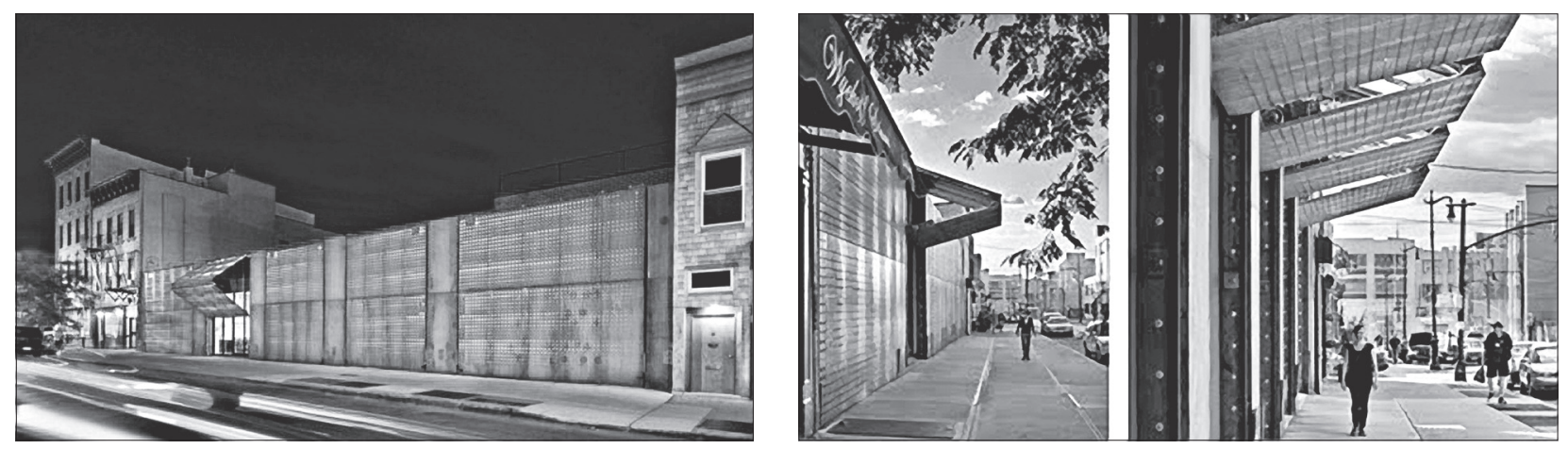

Figure 15. Vision of repurposing of former "Centroslavija" facilities Source of photo a: Internet 8; source of photo b: Internet 9

tion of supermarket. In fact, a large number of international supermarket chains are interested in expanding their work in the cities of Serbia (German "Lidl", French "Carrefour", etc.). At the end of 2010, "Lidl" was registered in Serbia and is currently in a phase of expansion and purchasing of land for the markets. "Lidl" has already bought land in Novi Sad at quarter Novo Naselje (Internet 10), but is interested in new locations in the city.

"Lidl" policy of doing business in Europe is buying land at different locations and opening of more facilities at the same time. This unconstructed area could be offered to the company as potential location for their supermarket (Figure 17). The advantages of

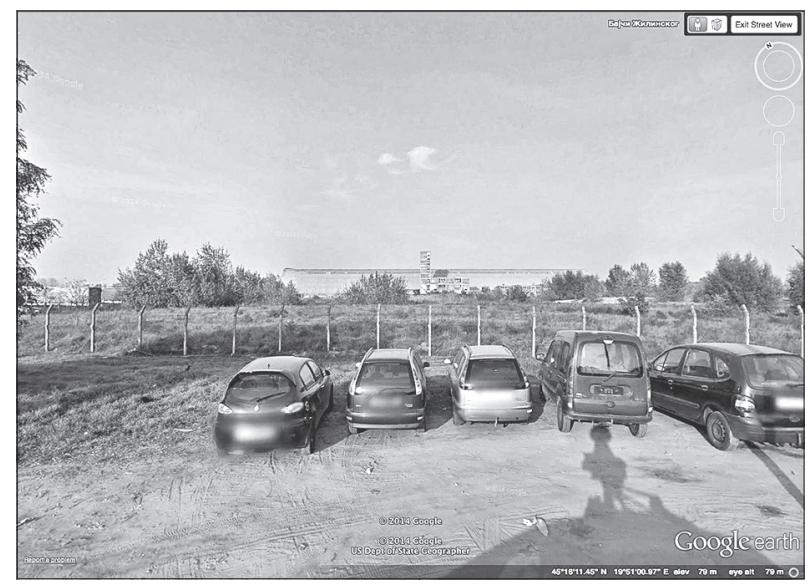

this location are: transport links, proximity of the city center (about $2 \mathrm{~km}$ ), a potential direct bus line that to leads to the supermarket, the potential number of customers (around 300000 inhabitants of Novi Sad), location near the DTD Canal and the Danube, etc.

\section{Transformation of industrial zones in other cities}

Relocation of industrial zone, the establishment of new industrial zone, transformation of certain industrial facilities within them, or even transformation of entire industrial zone is present in many cities, e.g. Budapest, Bucharest, Zagreb, Maribor, Milano, etc.

For the determination of industrial zones location in Budapest significant impact had the road net-

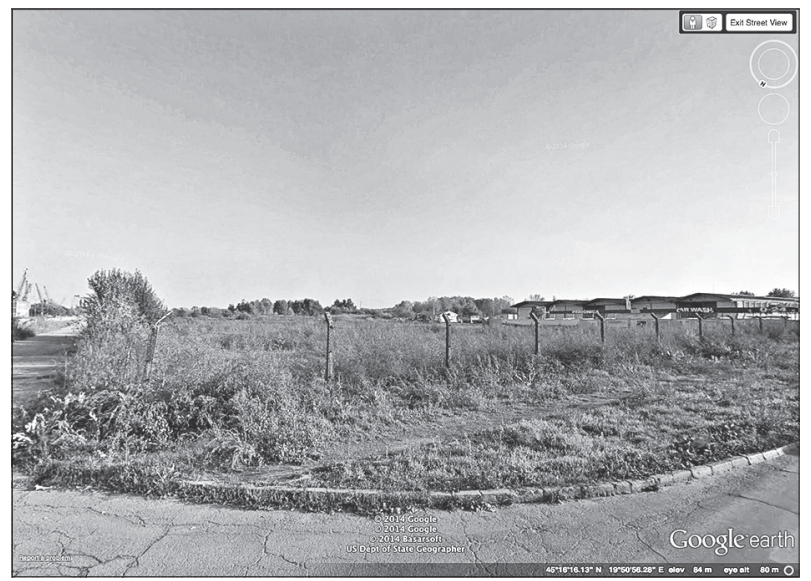

Figure 16. Unconstructed land area in the work zone "Sever III" Source of a and b photo: Google Earth (street view), 2014
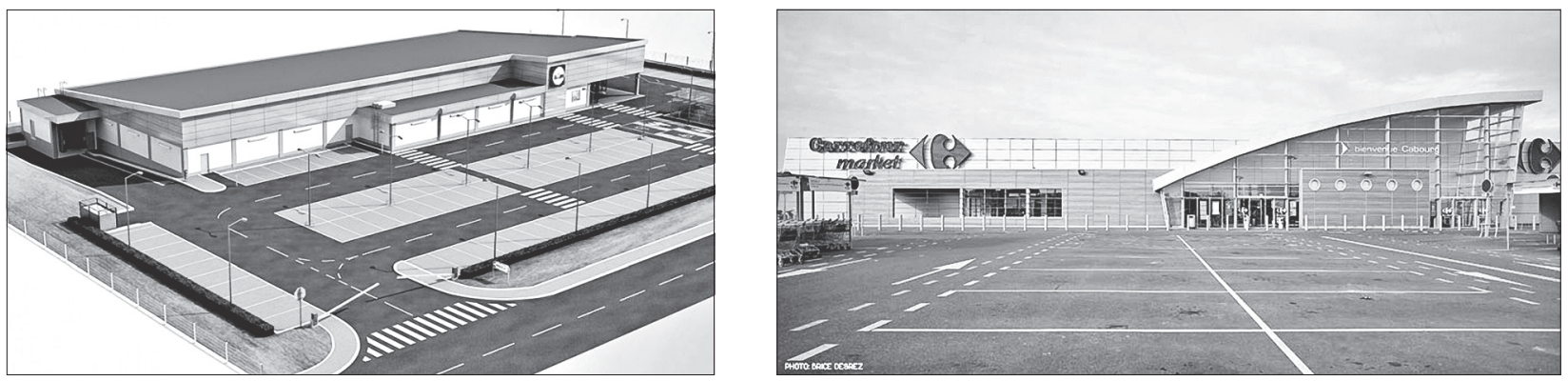

Figure 17. Vision of transformation of unconstructed land area into supermarket Source of photo a: Internet 10; source of photo b: Internet 11 
work and Danube. After the 1950 with Budapest were merged 23 settlements making industrial zones location inappropriate between the old city center and new settlements. As a result, new industrial zones were created within new, peripheral areas of the city, as well as the reuse of old industrial areas for new purposes (Barta, 2000).

Industrial zones of Bucharest, the most important industrial center and the capital of Romania, experienced significant changes at the end of the zoth century. During communism were founded large industrial zones within the city. At the end of the 2oth century are in progress reduction of their surface, privatization and their use for other purposes, primarily for logistics and trade. Often these changes occur spontaneously leaving old industrial facilities in process of decay (Mirea, et al., 2012).

At the beginning of 21st century, the industrial zones are being established on the periphery of the City of Zagreb, ea. at locations where there are free, larger unconstructed land areas. In this way were created business zones: Buzin, Jankomir, Stupnik, Lučko and others. The City of Zagreb did not invest in the construction or subsidized infrastructural equipment of the zones, except transportation infrastructure, but participated in the process of making of spatial plans for these zones and in the issuance of building permits and construction conditions (Internet 12).

The industrial city of Maribor is an important regional center in Slovenia. In 1961 business Tezno zone was established in Maribor. For Tezno zone was made constructive development plan in 2001, which included a productive and storing activities, communication, business sectors, agencies, public administration, commercial activities, hotel, industrial tourism, traffic, parking services, gas stations, etc. The zone has its own drawbacks, such as poor infrastructure in some

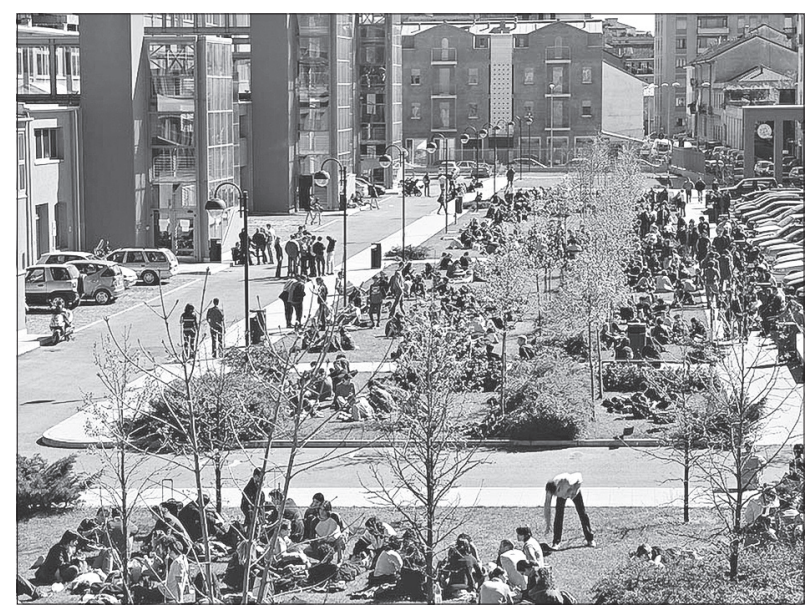

Figure 18. Students resting at Bovisa campus located in the former Bovisa industrial zone Source: Internet 14 sectors, which was not repaired since the period of the Second World War. Also, the drawback of the zone is the high price of land (Đukičin, et al., 2011).

Industrial areas of Milano, a very important industrial center of the Republic of Italy, have experienced significant changes during the second half of the 2oth century. A good example of this is Bovis industrial zone in the north of the city that has experienced a significant transformation. After numerous factories collapsed or were relocated away from the city center, this area generally became residential zone. At the end of the 2oth century in a former industrial area was established one of the campuses of the Polytechnic University (Figure 18). Today renovated factory building houses the main building of the Faculty of Architecture (Internet 13).

\section{Conclusion}

Industrial development of Novi Sad had begun in the late 19th century with the opening of textile and food factories. After the Second World War, priority was given to refining, metal processing, chemical and electrical industry.

In a number of benefits that the City of Novi Sad received in the Spatial Plan of the Republic of Serbia, its particular location on the Danube-Sava axis of development has special significance and the priority for the development of the Republic. Together with Niš, Novi Sad supports the strategy of demotropolization of the country.

Areas intended for business development in Novi Sad according to its position, content, activities and characteristics could be classified as city centers, facilities for business at exits and work zones.

The largest area for the development of economic activities is planned in established work zones that are regulated for the development of secondary and tertiary activities, port, freight- transport center, activities that need the possibility of water transport and the development of public utilities. Construction in work zones will be carried out in the free spaces but due to structural, technological, proprietorship and other changes that will happen in the future this will lead to their intensive use and cause a change in the use of spaces within the already formed complex.

This article presents examples of planning and transformation of objects of former chemical industry "Agrohem" and the Social Enterprise Holding "Centroslavija". For the area of the former "Agrohem" is given an example of the construction of the shopping center "Plaza River" which would entail the removal of the existing facilities. In addition, an example is given for the utilization of existing building for the purpose of its refurbishment in the restaurant. Ware- 
houses of former "Centroslavija" could be converted into buildings with retail stores. Similar was done in many world cities, like New York. In addition, an example is given how could be used vacant and unconstructed land in the working zone "Sever III". It is proposed to build a supermarket on the land area south of the complex "Agrohem".

There are numerous examples of planning, development and transformation of buildings and industrial zone land. Transformation of the industrial zones is present in Novi Sad as well as in other cities in the region (Budapest, Bucharest, Zagreb, Maribor, Milano, etc.). Planning, development and preliminary designs and constructions within the working zone "Sever III" in Novi Sad could lead to the employment of people and the revival of the neighborhood.

\section{References}

Barta, G. 2000. Industrial restructuring in the Budapest agglomeration. Research Support Scheme, Praha, Czech Republic, 37 pp.

Bogdanović, Ž., Carić, N., Bugarski, D., Jovanović, G., Laškov, M., Romelić, J., Đuričić, J., Tomić, P., Miljković, Lj., Bugarčić, P., Đurčić, S., Plavša, J. 1994. Novi Sad III. Geographical monography. University of Novi Sad, Faculty of Sciences, Institute of Geography, Novi Sad (in Serbian).

Ćopić, S., Đorđević, J., Lukić, T., Stojanović, V., Đukičin, S., Besermenji, S., Stamenković, I., Tumarić, A. 2014. Transformation of Industrial Heritage - an Example of Tourism Industry Development in the Ruhr Area (Germany). Geographica Pannonica 18-2, 43-50.

Đukičin, S., Milanković, J., Đorđević, J., 2011. Contemporary Business Trends and Industrial Transformation in Slovenia on the Examples of Maribor and Celje. Geographica Pannonica 15-3, 81-89.

Grčić, M., Ratkaj, I. 2003. Euroregions and eurocorridors as factors of integration of South Eastern Europe with the European Union. Proceedings of Faculty of Sciences-Geographical Institute 51, 1-22. (In Serbian)

Grčić, M., Ratkaj, I. 2006. Structural changes and regional differentiation of industry in Serbia during the period of transition (1988-2005). Bulletin of the Serbian Geographical Society 86-2, 97-112. (In Serbian)

Miletić R., Miljanović D., Todorović M. 2009. Industrial cities in transition: Problem areas. Bulletin of the Serbian Geographical Society 89-3, 191-206. (In Serbian)

Mirea, A. D., Vanau, G., Niculae, I. M., Dinca, C. 2012. Industrial Landscape Expansion and Evolution in
Bucharest's District 4. Forum geographic XI-1, 2635 .

Official Gazette of the City of Novi Sad, 2012. Spatial Plan of the City of Novi Sad.

Official Gazette of the City of Novi Sad, 2006. General Plan of the City of Novi Sad until 2021 (refined text)

Press releases of the Statistical Office of the Republic of Serbia, January 2014, July 2013, January 2013, January 2012 and January 2009.

Savić, S., Milošević, D., Lazić, L., Marković, V., Arsenović, D., Pavić, D. 2013. Classifying Urban Meteorological Stations Sites by "Local Climate Zones": preliminary results for the City of Novi Sad (Serbia). Geographica Pannonica 17-3, 60-68.

Stajić, V. 1941. Economy of Novi Sad from 1748 to 1880. Archive of Novi Sad magistrate, Novi Sad. (in Serbian)

Internet 1: http://www.geosrbija.rs/rga/default. aspx?gui $=1 \&$ lang $=3$

Internet 2: http://gdb.rferl.org/7D7FA7AF-B912-40FF9227-A92D056B128F_mw1024_s_n.jpg

Internet 3: http://s1218.photobucket.com/user/Nicisy/ media/561-predavanje-12pdf-AdobeReader.jpg. html

Internet 4: http://serbia.eastreal.net/Portals/26/ Novi\%2oSad\%2oshopping\%2ocenterdraft\% 2obrochure.pdf

Internet 5: http://www.desilva.pl/news/stara_ zajezdnia_en.htm

Internet 6: http://businesstraveller.pl/wp-content/ uploads/2012/11/zajezdnia-635x295.jpg

Internet 7: http://3.bp.blogspot.com/-T9bmSeHCDLY/ USVLS $533 \mathrm{HEI} / A A A A A A A A A o E /$ vzojKKQj2 Ks/ s160o/IMG_0592.jpg

Internet 8: http://inhabitat.com/abandonedwarehouse-tranformed-with-movable-steel-facade/ wycoffexchange- $3 /$ ? extend $=1$

Internet 9: http://1.bp.blogspot.com/_b5lABnOqz4s/ TUY_bcWXVJI/AAAAAAAAGSk/WQegqtcci4/ s40o/wyckoff\%2Bexchange2.jpg

Internet 10: http://novinenovosadske.rs/lidl-uskorona-novom-naselju/

Internet 11: http://www.cia-international.fr/tl_files/ editeur/images/Projets/Hypermarchesupermarche/ CARREFOUR\%2oMARKET\%2O(CABOURG)/ cabourg_carrefourooo4.jpg

Internet 12: http://www.zagreb.hr/default. aspx?id=13366

Internet 13: http://en.wikipedia.org/wiki/Bovisa

Internet 14: http://www.polimi.it/en/university/ campuses/milano-bovisa/ 